\title{
¿Géneros o estrategias? Discursos históricos y cinematográficos en el cine chileno de ficción ${ }^{1}$
}

\section{Genres or Strategies? Cinematographic and Historical Discourses in Chilean Film}

\author{
Hans Stange Marcus, Claudio Salinas Muñoz, Eduardo Santa Cruz Achurra \\ y José Miguel Santa Cruz Grau \\ Universidad de Chile, Santiago, Chile. Universidad de Barcelona. Barcelona, España. \\ hstangemarcus@yahoo.es; claudiorsm@yahoo.com; esantacr@uchile.cl; \\ josesantacruzgrau@gmail.com.
}

\section{Resumen}

Los discursos históricos en el cine, por lo general, han dado lugar a géneros cinematográficos. En el cine de ficción chileno, sin embargo, resulta necesario estudiar dichos discursos desde otro prisma. Este artículo propone tres estrategias estéticas por medio de las cuales las películas chilenas de ficción producen efectos de verosimilitud y se apropian de los discursos históricos: el comentario contextual, el refuerzo hegemónico o contrahegemónico y la subordinación narrativa.

Palabras clave: Cine chileno, historia, géneros cinematográficos, verosimilitud, sentido común.

\section{Abstract}

Historical discourses in cinema have generally given rise to cinematographic genres. In Chilean fiction films, however, a different scope is necessary to study its discourses. This essay proposes that it is possible to recognize three main aesthetic strategies by which Chilean fiction films use historical discourse in order to produce certain "verisimilitude effects": contextual comment, hegemonic or counterhegemonic reinforcement, and narrative subordination.

Keywords: Chilean cinema, history, film genres, verisimilitude, common sense.

1 Este artículo forma parte del proyecto La historia de Chile en el cine de ficción nacional, Fondecyt $\mathrm{N}^{\circ} 1160180$ (20162018). Queremos reconocer especialmente el aporte a este trabajo de los asistentes de investigación del proyecto, Carolina Kuhlmann y Cristian Ahumada. 


\section{La historia en lo cinematográfico}

Desde los años ochenta, la tensión entre las discursividades del relato histórico de los historiadores y de los cineastas ha supuesto un amplio espacio de convergencia de campos disciplinares inicialmente excluyentes -los historiadores, los teóricos e historiadores de cine y los cineastas-, lo que significó una revitalización sustancial de cada uno de estos ámbitos. La búsqueda de "rigor" historiográfico en la representación cinematográfica ha supuesto la incorporación activa y cada vez mayor de historiadores a los equipos de producción. Por su lado, los teóricos e historiadores del cine han visto cómo las transformaciones sociales estructurales de los últimos cien años han anulado la "historia del progreso técnico-industrial" en sus formas de representación, como único vector posible de su relato. Por su parte, los historiadores han asistido al encuentro de una batería casi "infinita" de fuentes (audio) visuales para complejizar sus propios estudios sobre los procesos históricos. Ejemplar sería, para el caso, un estudio del declive de la dinastía de los Romanov y del Imperio Ruso: cómo el propio material fílmico documental producido a petición del zar Nicolás II, para consagrar cinematográficamente su figura y la dinastía, devino tras el estallido revolucionario de 1917 en un discurso cinematográfico revolucionario en la trilogía de la cineasta Esfir Shub realizada entre 1927 y 1928.

A esta altura resulta evidente y hasta reiterativo plantear que las películas se escapan de los límites que se han puesto a los textos como fuentes históricas, ya que "los filmes no son simples repertorios de lo visible. En el marco relativamente estrecho que es el de las perspectivas de expresión y de comunicación en cierta época, intervienen permanentemente modificaciones, desplazamientos, reevaluaciones" (Sorlin 251). Las películas, bajo la interrogación historiográfica, se afinan ahí donde se dimensionan como "textos audiovisuales [que] expresan a la sociedad y lo hacen tanto a partir de la anécdota que cuentan, como de las formas elegidas para hacerlo, es decir, de los conjuntos y las articulaciones de signos que conforman cada texto" (Krieger y Tranchine 3). En las películas que ponen en escena una coartada histórica sucede, entonces, un doble proceso inmediato y casi indisoluble: al tiempo que construyen una versión del pasado -según los criterios estéticos, sociales y culturales de su contexto específico y/o ampliado-, en ellas mismas se está construyendo la historia de su propio tiempo. Un ejemplo evidente es el que trata Ferro a propósito de la ambientación anacrónica de los cuadros o representaciones de Stalin en películas soviéticas históricas, aun cuando este aún no era el secretario general del partido (35 y ss.).

El discurso cinematográfico sobre el pasado no debe ser extirpado de su particularidad: es un discurso con "derecho propio, mediante el cual podríamos ser capaces de decir algo diferente de lo que podemos decir en la forma verbal” (White 218). Incluso las "secuencias de tomas y el uso del montaje o primeros planos pueden ser hechos para predicar tan efectivamente como las frases, las oraciones, o secuencias de oraciones en el discurso hablado o escrito" (222). Pero, al mismo tiempo, su rela- 
ción con el pasado no resulta privilegiadamente de un ejercicio verista o incluso de reconstrucción de las estéticas predominantes de una época específica, a través de la ambientación tomada de modelos, cuadros, textos u otros referentes. Como ha insistido Metz, lo que está en juego es lo verosímil cinematográfico, y guardaría más relación con ciertas convenciones de género y estrategias retóricas, que con una pretensión de reconstrucción del pasado y/u objetividad científica (Metz 17 y ss.).

\section{Discursos sociales y discursos cinematográficos}

Lo discursivo aquí se está tensionando en dos dimensiones y, con ello, buena parte de la confusión de las relaciones entre cine e historia, entre historiografía e historia y entre cine e historiografía. Por una parte, el discurso es la producción de sentidos socialmente construidos y legitimados mediante prácticas institucionales y políticas, es decir, discursos sociales como el discurso de género, el científico, el judicial, el histórico, etcétera. A partir de ellos se forman corpus representacionales que contribuyen a la producción de imágenes y concepciones de mundo o sentidos comunes, a la vez que se implican prácticas sociales en que existe una disputa sobre la hegemonía de los imaginarios colectivos simbólicos y de las mismas formas de producir esas representaciones. Por otra parte, la noción de discurso refiere también a los modos y medios de representación de la realidad que se cristalizan en películas, textos, pinturas, edificios, canciones, etcétera. Estos median los hechos sociales y otros discursos e imaginarios, a guisa de intertextos o expresiones formales de relaciones sociales no necesariamente institucionalizadas, pero dentro de un orden social, epocal y culturalmente situado, por ejemplo: el discurso literario, el cinematográfico, el televisivo, el fotográfico, el pictórico, entre otros.

El discurso cinematográfico sería, entonces, parte de los sistemas discursivos de representación, "aquellos sistemas de significado a través de los cuales representamos el mundo ante nosotros mismos y ante los demás" (Hall, "Representación" 45), en los que se disputa abiertamente por la hegemonía interpretativa de la realidad, pero no en su dimensión de contener una idea o concepto específico, sino entendiendo que "el discurso no es simplemente aquello que traduce las luchas o los sistemas de dominación, sino aquello por lo que, y por medio de lo cual se lucha, aquel poder del que quiere uno adueñarse" (Foucault 12). Tales sistemas discursivos de representación operan inicialmente en tres formas:

1) reflectiva: cuando existe una serie de convenciones que activan a la representación como reflejo del mundo de los objetos, esa exterioridad a lo humano que constituye el mundo;

2) intencional: cuando el privilegio de la representación es el vehículo de un sentido individual o personal;

3) construccionista: el sentido que constituye la exterioridad de lo humano se construye en y mediante el lenguaje (Hall, "El trabajo" 445). 
La representación opera también como sustituto de aquello que refiere, es decir, está en lugar de otra cosa, marca la presencia de una ausencia que, en su propio despliegue, genera un suplemento o un incremento de la convención de realidad de esa cosa, enmarcado en un momento epocal específico que, en este caso, sería un engrosamiento o adelgazamiento de su efecto historizante:

Como es sabido, el concepto de representación, desde un punto de vista etimológico, tiene una doble acepción: la de ausencia (la representación es el objeto que sustituye a lo representado) y la de presencia (imagen sustitutiva con sentido simbólico). El cine por definición expresa doblemente este carácter. En primer lugar, como escenificación filmada. En segundo término, como representación de prácticas y usos sociales externos al film. Desde una perspectiva histórica, muchas veces, hemos de hablar, incluso, de un tercer nivel de representación, puesto que el film expresa acontecimientos ya sucedidos (Rueda y Chicharro 429).

En esta dirección, la cuestión sustancial será si las películas chilenas relativas a la historia deberían comparecer a las clasificaciones, por ejemplo, de Ferro, que divide el género histórico entre aquellas ficciones históricas donde las necesidades estéticas priman frente el "rigor" de los sucesos y las reconstrucciones históricas donde se despliega de forma manifiesta un discurso sobre el pasado (6-33). Sería atingente ponerlas a la luz de lo que Rosenstone clasifica (48-9) con la noción de historia como drama, que a partir de la ficcionalidad narrativa delimita un período histórico concreto, frente a la historia como experimentación, donde el discurso intencional de un cineasta genera rupturas, en un mismo gesto, con las formas de representación de lo histórico cinematográfico, y con los propios sentidos comunes sobre un personaje, evento o período.

Encontraríamos aquellas claves entre las películas con valor histórico/sociológico propuestas por José María Caparrós, esas que se transforman en testimonios de las mentalidades del período de su producción, las de género histórico, que evocan a eventos y personas reales que fueron más o menos relevantes en el pasado, o bien las de intencionalidad histórica, donde lo relevante se encontraría en ese discurso que intenta hacer historia sobre el pasado ( 25 y ss.). Podríamos presionar también este corpus de películas para encajarlos en lo que Monterde, Selva y Solá han propuesto como ficciones de época (136-46), donde los períodos del pasado son telones de fondo para una narración que podría acontecer, en lo sustancial, en cualquier contexto; ficciones históricas documentalizadas, donde los eventos y/o personajes históricos son los que estructuran el relato; y por último, en el ensayo histórico ficcional donde, nuevamente, lo que comparece es esa individualidad que propone un discurso histórico pleno, con el propósito de que provoque un conocimiento histórico en el espectador.

¿Es posible desplegar una batería de categorías como biopic, cine de ambientación histórica o cine de hechos/eventos históricos para depositar las producciones locales? El problema es, precisamente, que no podemos pensar al cine chileno -por lo menos hasta el momento- como una plataforma de construcción de un género y/o 
subgéneros cinematográficos relacionados con la historia. El cine chileno carece de un volumen productivo que sustente el desarrollo de un género histórico, a diferencia de lo que ocurre en Estados Unidos, China o Europa, por ejemplo. Que exista un puñado de películas que permitan ser interrogadas por la relación entre cine e historia no supone, en sí, la configuración de un género. Lo que consideramos la carencia de la articulación de un género o subgéneros históricos, obliga a construir una batería de conceptos que respondan necesariamente a la especificidad material local, dentro de un marco de problemas y perspectivas relativamente consagradas sobre la relación cine e historia.

Entonces, ¿puede el cine chileno hacerse cargo de la verosimilitud histórica sin haber constituido propiamente géneros cinematográficos históricos? Nos referimos, por ejemplo, al Heritage Film inglés o el Western estadounidense, géneros a partir de los cuales reconocemos y discriminamos esas retóricas o estrategias estéticas que configuren la estructura interpretativa del pasado o -en un espectro más amplio- la pregunta por el sentido del pasado. Si no es el caso, ¿cómo se enfrentan, padecen y relacionan los "sistemas discursivos de representación" del cine con el discurso histórico, concebido como esa agrupación heterogénea de saberes sociales sobre el pasado? Esta encrucijada desactiva el conflicto aparentemente central del estatuto de realidad que construyen el cine y la historiografía cuando narran el pasado; lo que interesa ya no es el grado de complementariedad, subordinación o suplementariedad entre el campo historiográfico y cinematográfico, sino cuáles son las formas específicas que lo cinematográfico despliega para su verosímil histórico y efecto de realidad, a partir de las estructuras narrativas que movilizan causalidades, valoraciones, esbozan caracteres y psicologías individuales y colectivas. Asimismo, la gestualidad de los personajes, los diálogos precisos que se les atribuyen, las emociones que despliegan, las locaciones en que desarrollan sus acciones, las relaciones personales y sociales que entablan, pero también la posición de la cámara, la duración de la secuencia, el orden causal sugerido por el guión, la música, el vestuario y la "ambientación". En resumidas cuentas, cuáles son las estrategias de verosimilitud desplegadas ahí cuando el cine imagina el pasado de Chile.

\section{El efecto de verosimilitud histórica}

Hemos llegado a una estación donde dos conceptos protagonizan el "sistema discursivo de representación" cinematográfico cuando construye fragmentos de la historia y, en nuestro caso, de la historia de Chile. Verosimilitud y efecto de realidad se conjugan para establecer el pacto de identificación, análisis y significado con los espectadores imaginarios de una u otra película. En esto, resulta central pensar lo verosímil en tanto la representación de un mundo posible, y no de la veracidad efectiva de los eventos: la construcción de un mundo posible, ese estado de cosas previsto por el 
espectador. El mundo posible no es una imposición, sino una verificación por parte de los espectadores de un estado de cosas de acuerdo con la propuesta del discurso -en contraposición a la idea de representación en tanto espejo de la realidad o como pura invención del individuo o equipo de producción-.

La idea de mundo posible supone una conciliación entre lo que se representa y lo que se conoce, cuestión por lo demás común a cualquier forma de producción comunicacional, como por ejemplo, el propio periodismo (Alsina 29-34). Esto debido a que, en definitiva, está relacionada con una cuestión mayor ya planteada por Goldmann con su noción de conciencia posible (9-10), que se refiere a que un grupo social determinado, dada la estructura de su conciencia real -en términos marxistas-, resultante de su pasado y de múltiples acontecimientos que obraron sobre ella, permite o no el paso de cierta información o contenido discursivo y así establece cuáles son los límites que tiene su conciencia, históricamente determinada.

Hay una construcción de la realidad que varía según lo que se considere "realidad". La realidad social no puede ser distinta a cómo los actores sociales la significan, comprenden y reelaboran en sus representaciones; por ello, es una visión generativa de la realidad. Lo verosímil no es lo simplemente similar a su referente, un despliegue mimético de la representación, sino que es lo habitual, lo que sucede la mayor parte de las veces. Bettetini y Fumagalli afirman que sostener un eikòs (un enunciado habitual o probable) puede tener más valor que afirmar un hecho como verdadero (47). El hecho puede ser algo particularmente contingente, un acontecimiento, una cuestión denotativa. En cambio, lo verosímil -su despliegue- importa necesariamente una connotación, que da cuenta del razonamiento y del lugar de la enunciación de quien nombra y participa de la comunicación. Lo verosímil nos entrega más información de la "realidad" del mundo de lo que pueda comunicar la mera constatación de la contingencia. En este sentido, lo verosímil es una operación, una creación social y una configuración de mundo, que remite a la organización de sentido de una colectividad humana.

Esta dimensión generativa es clave para entender la relación entre lo verosímil con los géneros cinematográficos. El despliegue de la verosimilitud supone el cumplimiento de normas, reglas o códigos, a través de los cuales la organización del discurso y sus contenidos se condicen con lo sabido, una forma no necesariamente sincrónica de verificación de lo habitual. Es por ello que los géneros organizan un juego de expectativas y reconocimientos, a partir de los que se constituye finalmente la "verdad del discurso", es decir, la verificación de esa reunión variopinta de creencias sobre un hecho, persona o proceso del pasado específico. El género reclama una dimensión de corpus productivo textual, sonoro y visual que lo constituye; tiene evidentemente una naturaleza intertextual, que se expone en la superficie misma de las películas y cuya operatividad se sostiene sustancialmente en su acumulación en el tiempo: "lo verosímil se establece no en función de la realidad, sino en función de textos (filmes) ya establecidos. Surge más del discurso que de la verdad: es un efecto de corpus" (Au- 
mont et al. 24). Esto constituye el sustrato colectivo del dispositivo discursivo que es vehiculizado por lo verosímil:

1) contenidos y códigos compartidos;

2) la adhesión a cierto canon que establece el sentido histórico;

3) la movilización de expectativas que preparan la recepción de una obra;

4) y una estructura de producción.

Si lo verosímil está lejos de ser lo idéntico a la realidad, sino que apela a las formas habituales de pensar, interpretar y proyectar dicha realidad al interior de una serie de convenciones genéricas al interior de las películas, lo verosímil está sujeto especialmente a criterios de verificación discursiva, por lo menos, en relación a: 1) la coherencia interna-lógica de la película, que las causalidades sean probables; y 2) la correspondencia externa de la película, que lo representado se "parezca" a lo conocido, a como pensamos la realidad.

Estos criterios de veridicción del discurso deben imponerse de un régimen discursivo cuyas condiciones fueron ya reconocidas por Michel Foucault. En primer lugar, la prohibición, es decir, el conjunto de aquellos enunciados que son decibles dentro de un marco de sentido, y el conjunto de los otros que no pueden serlo. Lo indecible está configurado por dos grandes corpus de enunciados: el primero, corresponde a aquellos no válidos dentro del orden de los saberes, es decir, que carecen de los criterios mínimos de pertenencia (y pertinencia) al discurso histórico; el segundo, a todos aquellos enunciados que no pueden ser concebidos por el horizonte de sentido de una época que, leído en términos lacanianos, sería lo real, lo que simplemente no es posible concebir hasta que lo es (Foucault 5-6).

En segundo lugar, la oposición entre razón y locura, es decir, el conjunto de aquellos eventos que se configuran entre lo probable y lo improbable. Ambos polos también se configuran en dos sentidos: en su dimensión de lo habitual o inhabitual, lo que ha venido ocurriendo o lo que difícilmente puede suceder; y en su dimensión de lo que puede ser probado y todo eso que, al no ser probado frente al discurso, deviene en locura (Foucault 6-8).

Pero, al mismo tiempo, la verosimilitud posibilita proyectar - de forma no lineal ni necesariamente consciente por parte del equipo de producción- un espectador imaginario que trasciende la especificidad de su época de producción. A modo de ejemplo, a la luz de El húsar de la muerte (Pedro Sienna, 1925), lo verosímil posibilita el reconocimiento de Manuel Rodríguez en el cuerpo de Pedro Sienna. En relación a esas reuniones de saberes heterogéneos sobre el personaje, esos que llegan a nuestro presente, que permiten una continuidad histórica en el sentido común, es verosímil que Manuel Rodríguez le haya abierto la puerta del carruaje a Casimiro Marcó del Pont; pero resulta difícil concebir que este mismo haya sido un doble agente del Reino de España o, incluso, algo absolutamente posible: que alguna vez le haya abierto la puerta del carruaje a Bernardo O'Higgins o haya compartido una noche de fiesta con 
él. Ninguno de estos actos puede ser certificado por las fuentes de la historiografía, no obstante, solo uno de ellos se nos vuelve verosímil en el presente. Planteamos una interpretación posible: en el efecto de verosimilitud se encuentra la posibilidad de supervivencia de una película en el tiempo como agente activo de construcción permanente del sentido común. Cuando el efecto de verosimilitud estalla desde su propio interior, la película -también cualquier texto, objeto o imagen- deviene en otra cosa, solo comparece en el presente en su condición de huella de su propio presente ya lejano.

\section{El efecto de realidad histórico-cinematográfica}

Las representaciones históricas cinematográficas tienen que producir un efecto de realidad para que el despliegue del discurso histórico no devenga en una ciencia ficción sobre el pasado. Un ejemplo evidente de ello acontece en la película 10.000 AC (Roland Emmerich, 2008). El efecto de realidad es el vehículo para que lo habitual se fije en una constelación de formas de representación convenidas en una estética social de lo verdadero:

aquello que se dice de la realidad tiene efectos de verdad, y que ello no depende de que lo dicho sea verdadero, falso o ficticio. Tal tesis supone un problema que tiene que ver con la narratividad, la hermenéutica y la ficción. En primer lugar, porque lo que se dice del mundo (narraciones) se puede hacer de muchos modos más o menos acertados unos y otros: en ello va el problema de la narratividad, sobre el modo como se producen estas narraciones y si ellas responden a los relatos (ideas) que las guían. En segundo lugar, porque esas narraciones han de poder ser comprendidas, se debe poder entender el relato que las guía y relaciona con otras y en ello le va su calidad hermenéutica. En tercer lugar, aparece la ficción, porque no se pueden hacer narraciones ni se las puede querer interpretar si ellas están compuestas por verdades o falsedades categóricas. Esto se debe a que si alguno quiere entender el mundo, lo primero que va a hacer es buscar la coherencia en lo dicho, y lo segundo, la utilidad de ese relato (Guzmán 2).

Esta constelación de formas que configura el efecto de realidad de la ficción cinematográfica, es donde el espectador podría desplegar sus saberes socialmente construidos para reconocerse, a través de su memoria emotiva-intelectual, en los elementos que expone una película, pero también -casi como un perito historiadorverificar o cuestionar la coherencia interna de dichos elementos. Para ejemplificar esto, podríamos utilizar dos películas que han marcado dos momentos intensos y ampliamente discutidos de la relación entre sentido común, el pasado y el efecto de realidad.

Por un lado, Machuca (Andrés Wood, 2004) desplegó una serie de formas cinematográficas de ambientación epocal y lógicas socioambientales de reconocimiento 
del año final de la Unidad Popular en 1973, mediante una serie de procedimientos estético-narrativos que reclamaban una transformación en las maneras de filmar películas en Chile, construyendo un tipo de imagen que después veremos replicadas hasta en series televisivas como Los archivos del cardenal (TVN, 2011). Algunos de esos elementos sustanciales serán la utilización de cámaras en mano y una imagen desaturada, pero con alto contraste. Alejándose a esa imagen en technicolor o en blanco y negro propia de las películas de los años sesenta y setenta, pero también de la lógica de los conflictos del período, consolidando la lectura del nunca más propio del devenir de la reconciliación nacional (Cortés y Berríos s.p.). Por el contrario, No (Pablo Larraín, 2012), partiendo de las formas de grabación de video U-MATIC de los años ochenta y con lógicas de fragmentación visual y narrativa propias de lo que vendría a ser una estética audiovisual contemporánea, despliega una narrativa que desea desarticular cierto discurso épico de la campaña del No, realizado por la Concertación de Partidos por la Democracia. Es decir, pretende poner en duda ciertos aspectos del sentido común sobre dichos eventos que ha edificado el propio imaginario televisivo local.

La primera película fue aplaudida, tanto por su reconstrucción de época como por dar cuenta de los conflictos que llevaron al 11 de septiembre de 1973, aunque no explique los procesos político-sociales que lo posibilitaron y se concentre en el drama de la amistad rota entre dos adolescentes, metáfora del quiebre del pacto de clases entre esa elite intelectual de izquierda y la fuerza productiva del pueblo. La segunda película, por su parte, fue cuestionada por realizar una lectura sesgada y poco realista del proceso del plebiscito, principalmente bajo el argumento generalizado de que dicha campaña no fue solo una batalla entre publicistas, es decir, resulta verosímil que todo ese proceso político pueda haber dependido tan solo de la mente brillante de un individuo. Por otro lado, si cuestionamos formalmente ambas películas, el ejercicio de Machuca podría ser menos apegado a una verdad histórica, entendida no solo como el acaecimiento de una serie de hechos comprobables o la exposición del sentido de los procesos que ocurrieron, sino también como la reconstrucción del "ojo de esa época", determinada por una serie de limitantes tecnológicas, ideológicas e histórico-culturales específicas; mientras No pareciese intentar dar cuenta de ese tipo de ojo epocal, que se fue edificando a partir de la textura de lo televisivo, lo individual, lo publicitario y lo mercantil, y que configuran buena parte de nuestro sentido común actual (Santa Cruz Grau s. p.; Richard s. p.).

El efecto de verosimilitud arraiga las imágenes en el espectador de su presente, en los códigos de lectura situados, en lo que podríamos llamar su campo de lectura y visualización atingente e inmediato. Por el contrario, el efecto de realidad está ahí en las formas en que se construye la audiovisualidad de la película, en la expresión evidente de las convenciones y posibilidades cinematográficas de la época. Por ejemplo, en la secuencia en que Pedro Sienna caracteriza las múltiples identidades que asumía Manuel Rodríguez para despistar a los realistas, en esa serie de primeros planos encadenados 
donde aparece "disfrazado" como un bandolero, un campesino, un soldado realista, hasta como pirata en la mente de Vicente San Bruno, todos estereotipos visuales que pertenecen a los inicios del siglo xx, y no necesariamente a inicios del siglo xIx. A partir de aquí, podríamos plantear que la verosimilitud, en su régimen estético, está determinada por la relación activa entre el efecto de verosimilitud y el efecto de realidad, transformándose así en un puente formal entre lo representado y lo probable/habitual. Lo verosímil no es un atributo del texto, objeto e imagen estética, pero tampoco del colectivo social y de los individuos que lo interpretan, lo verosímil es una cualidad estética relacional, sujeta al arbitraje de su constitución.

Para plantearlo de una manera gráfica: la forma fílmica se posa sobre un tejido de convenciones compartidas, tanto por los espectadores como por los productores o realizadores, un trasfondo discursivo y representacional que configura lo que se podría definir como un sentido común audiovisual, compuesto por los repertorios representacionales verosímiles cultural y epocalmente situados. Este sentido común, en tanto materialización general de una cierta visión de mundo, es uno de los grados o niveles en que se manifiesta la ideología. Constituye su rasgo más fundamental y característico ser una concepción de mundo disgregada, incoherente e incongruente, conforme a la posición social y cultural de las multitudes, para los cuales constituye su única filosofía de vida (Gramsci 9-25). Se trata de una filosofía espontánea, por oposición al nivel de la concepción de mundo elaborada y sistemática constituida por la teoría. Sin embargo, cabe aclarar que la noción de espontaneidad no tiene relación con alguna originalidad, sino que, por el contrario, se refiere a que es vivida y, sobre todo, aplicada en lo cotidiano, sin reflexión y sin siquiera conciencia de sí misma. Dicho de otra forma, son fragmentos abigarrados y heteróclitos de explicaciones de la vida que asumen el carácter de lo natural, de aquello que no tendría ni necesitaría explicación, "que es porque es".

El sentido común no es una masa homogénea de creencias, más bien es fragmentario, "está hecho de la sedimentación de diversas concepciones del mundo, de tendencias filosóficas y tradiciones que han llegado fragmentadas y dispersas a la conciencia de un pueblo. De ese "sentido común" se tomarán referencias y ordenamientos que justifiquen o reprueben los actos de la vida pública y privada” (Paoli 75). Y tampoco es unitario, está compuesto por varios sentidos comunes diferentes que, de forma diacrónica, se despliegan al interior de una comunidad o colectivo en el devenir histórico de la misma: "El sentido común se ha ido plasmando en el lenguaje, en los ritos, en las supersticiones, los proverbios, las historias, y en toda una gigantesca gama de representaciones. Todas ellas tienen su coherencia histórica” (76).

La configuración de un sentido común audiovisual, al interior de un sentido común social más amplio, casi como un subconjunto del mismo o, más bien, una reunión de subconjuntos de fronteras porosas posibilita esas transferencias de aquellos repertorios inicialmente disímiles o históricamente diferenciados: "El sentido común se desarrolla y define en interacción con el ordenamiento de la vida social. 
La adhesión o repudio de una alternativa política reestructura el pensamiento, reformula sus modos de operar" (76). Por ello, el sentido común se configura en un espacio de disputa de los diferentes agentes sociales que luchan por la hegemonía interpretativa de ese:

cuerpo de creencias acerca de los objetos en nuestro ambiente, de la naturaleza de nuestras interacciones con estos objetos, y de los medios por los que podemos adquirir conocimiento de tales cosas. En su conjunto, podemos asumir que este cuerpo de creencias es verdadero. Esto no se debe a que las creencias del sentido común tengan garantizada de cualquier modo su verdad. Como todas las creencias, ellas son falibles, sin embargo, tienen una fuerte presunción prima facie a su favor. El sentido común tiene una pretensión a priori (Sankey 51-2).

Si la verosimilitud estética, para su presente, vehiculiza un sentido común audiovisual que está configurado en su relación de transferencia con otros sentidos comunes sociales, la propia verosimilitud estética es un territorio de disputas por la hegemonía interpretativa de ese cuerpo de creencias, que establecen nuestra relación con el medio ambiente de objetos con los que nos relacionamos y los cuales fijan nuestro horizonte de sentido. Por tanto, la verosimilitud está sujeta a transformaciones de sus modos de operar al interior de la vida social y presionada por las fluctuaciones político-sociales que las determinan. Así, todo discurso histórico verosímil buscará solidificar un mundo de creencias o poner en cuestión alguno de sus supuestos. Para esto luchará por transformarse con el propósito de construir una forma fílmica que se muestre naturalizada, haciendo de ese modo evidente la dimensión política e ideológica de todo discurso sobre el pasado, de toda película que vehiculiza ese discurso y de todo texto historiográfico que le reclama la ausencia de rigor "histórico" o lo certifica.

Consideramos que la manera de hacer visible las estrategias de verosimilitud cinematográfica se puede establecer en el análisis de cinco problemas:

a) Los archivos activados por la representación fílmica: la apariencia de realidad obtenida desde los archivos artísticos, mediáticos, etc.

b) La temporalidad: cercanía y lejanía con los acontecimientos representados, y con los filmes que los representan.

c) El compromiso emocional o vivencial: la representación de la historia leída/oída vs. la representación de la historia vivida/recordada/conversada.

d) La forma cinematográfica: el patrón o estructura de composición entre los elementos del sentido común audiovisual, los núcleos narrativos y la puesta en escena. Es la "solución formal" de la estrategia.

e) El "género" o contrato implícito entre película y espectador, que coloca los límites de lo representable y de lo posible. 


\section{Estrategias de la forma fílmica sobre la historia en el cine chileno}

Iniciábamos este texto con una idea fuerza: la relación entre historia y cine chileno tiene un problema estructural, que impide pensar las películas históricas bajos las categorías de género cinematográfico, aun cuando pudiésemos hacerlo. La certificación de que se han hecho 5, 10 o 15 biopic en más de cien años de producción, evidenciaría que ha sido una forma más o menos recurrente de construir un discurso sobre el pasado. Una evidencia factual que se podría desprender solo leyendo la mayoría de los títulos de las películas. Nuestra intención ha sido identificar cómo las películas chilenas han construido sus discursos sobre el pasado en distintos momentos a partir de un análisis desde el presente.

El rol privilegiado que estamos otorgando al presente tiene varias dimensiones: a) en una dimensión productiva, a partir del siglo xxi se ha realizado casi el $60 \%$ de las películas que construyen, de alguna u otra forma, una imagen sobre el pasado (ver tabla 1); b) en una dimensión discursiva, un grupo importante de esas películas, detrás de la coartada narrativa sobre el pasado, despliegan una reflexión sobre problemas de su presente inmediato, es decir, no solo filtran el pasado desde un punto de vista del presente -ejercicio inevitable-, sino que ponen en imágenes una tesis o un discurso sobre el presente; y c) en una dimensión material, la mayoría de estas despliegan una fascinación tecnológica por la reactualización de las imágenes del pasado, es decir, una suerte de presentismo técnico, asociado a las posibilidades que otorgan las transformaciones tecnológicas del cine y el audiovisual, donde se clausura la particularidad visual del pasado.

En la infertilidad de obligar a las películas a comparecer en una grilla categorial, el análisis de las propias operaciones materiales de las películas nos posibilitaron perfilar lo que hemos definido como tres estrategias estéticas generales que se han realizado cuando el cine chileno ha imaginado el pasado, inferidas a partir del análisis de las propias películas. Esta categorización no es excluyente, en una película pueden presentarse dos o tres estrategias combinadas:

a) Comentario contextual. El cine combina elementos históricos con elementos de los sentidos comunes imperantes en una época y sociedad para dotar de verosimilitud a sus relatos sobre un fenómeno actual. Así, un tema contingente -el aborto, el abuso infantil, la violencia intrafamiliar- es dotado de "densidad" histórica. Esto es lo que ocurriría, por ejemplo, en películas como Bombal (Marcelo Ferrari, 2011), Violeta se fue a los cielos (Andrés Wood, 2011), Teresa (Tatiana Gaviola, 2009), A la sombra del sol (Silvio Caiozzi y Pablo Perelman, 1974), La tierra prometida (Miguel Littin, 1973) o El baño (Gregory Cohen, 2005), entre otras.

b) Refuerzo hegemónico o contrahegemónico. El cine legitima o desacredita distintas versiones del discurso histórico, con el fin de representar el presente desde intereses ideológicos o identitarios. De esta manera, el componente histórico de una 
película se integra o refuerza el imaginario de un colectivo social o generacional, o bien como contribución a una mitología política, como ocurriría, por ejemplo, en las películas La pasión de Michelangelo (Esteban Larraín, 2012), El húsar de la muerte (Pedro Sienna, 1925), El bosque de Karadima (Matías Lira, 2015), Si mis campos hablaran (José Bohr, 1947), Caliche sangriento (Helvio Soto, 1969), Dawson Isla 10 (Miguel Littin, 2009), Machuca (Andrés Wood, 2004), Allende en su laberinto (Miguel Littin, 2014), entre otras.

c) Subordinación narrativa. El cine no tiene por objeto la reconstrucción verdadera de los hechos históricos, sino la producción de interpretaciones verosímiles sobre su significado social, con fines propios de la representación cinematográfica (crear atmósferas, dotar de ambiente, producir el efecto de extrañeza o exotismo, exacerbar lo pintoresco, entre otros). En este tipo de películas, el discurso histórico está subordinado al dispositivo cinematográfico por completo, disminuyendo de manera relevante la importancia del efecto de verosimilitud, cuyos "contenidos históricos" quedan también subordinados a los saberes sociales sobre lo propiamente cinematográfico. Este sería el caso de películas como Monvoisin (Mario Velasco, 2009), Tony Manero (Pablo Larraín, 2008), Mi mejor enemigo (Alex Bowen, 2005), No (Pablo Larraín, 2012), Un salto al vacío (Pablo Lavín, 2007), Postmortem (Pablo Larraín, 2010), Casa de remolienda (Joaquín Eyzaguirre, 2007) o Subterra (Marcelo Ferrari, 2003), entre otras.

Estas estrategias estéticas nos abren una serie de interrogantes que es necesario seguir profundizando, para delimitar de mejor forma las relaciones de significación que el cine chileno ha generado, principalmente ahí cuando se interrogan los usos o funciones sociales de dichos discursos proyectados por las ficciones cinematográficas. ¿Cómo se entroncan en esos campos de saberes y discursos que están construyendo las ideas hegemónicas del sentido común sobre el pasado?

Se ha señalado que la ficción audiovisual es especialmente significativa, ya que recoge y amplía la tradición de la narración oral, de tal manera que:

Sin representar ni deformar propiamente la realidad, las historias narradas [...] más bien la reescriben y la comentan, ocupando un lugar preeminente en las esferas de las "prácticas interpretativas" mediante las cuales en cada época los hombres han creado sus propias visiones y versiones del mundo y han dado sentido a la vida cotidiana (Buonano 62).

En esa dirección, las películas históricas desarrollarían tres funciones fundamentales. En primer lugar, nos hablan "a nosotros y de nosotros". Para ello, recogen, y reelaboran los temas e intereses elementales y básicos de la vida cotidiana: el bien y el mal, el amor y el odio, la familia, la amistad, la violencia, la justicia, la enfermedad y la salud, la felicidad y las desgracias, los sueños y el miedo, los cuales operan sobre la base de géneros y formatos ya conocidos. En segundo lugar, continúa Buonano, 
cumple un rol de familiarización con el mundo social, para preservar y construir un sentido común compartido, entendido como "un substrato de creencias y aceptaciones compartidas, incluso de respuestas a los dilemas de la existencia, que a su vez sirven para familiarizarnos con el mundo social" (64).

Lo antes dicho conduce a la tercera función que, en palabras de Buonano, sería la de mantenimiento de la comunidad, mediante la preservación y reconstitución de ámbitos significativamente reconocibles, como "lugar de regreso, expresión y reafirmación de los significados compartidos", operando como mucho más que un corpus internamente coherente y homogéneo (66).

\section{Reflexión final}

En última instancia, lo señalado abre otro espacio de problemas, que se refiere a si estas categorías propuestas son lo suficientemente plásticas para dar cuenta de aquellas películas que se hicieron durante el siglo xx y lo que va del xxi. Es decir, si en el análisis de las películas el comentario contextual no está referido a desplegar una reflexión sobre el presente, sino de leer el pasado con las lógicas de su presente, por ejemplo, en Si mis campos hablaran (1947), de José Bohr, o en la ya citada El húsar de la muerte (1925).

La contingencia de cada ejercicio categorial supone problematizar su determinación histórica, elemento necesario a la hora de situar nuestro trabajo analítico. Cuestionar nuestros propios supuestos categoriales es hacer evidente la pertenencia a esos mismos sentidos comunes en disputa, que se articulan en estrategias estéticas cinematográficas para generar un verosímil sobre el pasado y para, finalmente, hablar sobre el presente.

La intuición teórica que se puede desprender de todo el recorrido propuesto es que dichas estrategias estéticas se configuran en el encuentro de lo que podríamos denominar los discursos sociales contingentes sobre el pasado y el presente. Estos discursos se hayan disueltos en un sentido común múltiple y fragmentario, compuesto por núcleos de sentido común, diversos y asincrónicos, con las prácticas y formas culturales y artísticas contextuales que, a su vez, están disueltas en ese sentido común audiovisual.

Lo anterior se cristaliza en una imagen cinematográfica o en una forma fílmica específica vehiculizada por la experiencia emocional, sensorial e intelectual particular de ese grupo de individuos que la realizan, al interior de esa constelación de creencias y condiciones productivas en las que habita.

El presente texto ha instalado ciertas preguntas y problematizaciones que intentan demostrar que el cine chileno ficcional, ha recurrido al discurso histórico para generar discursividades visuales que quieren dar cuenta y explicar el presente de la realidad social. En esa dirección se sostiene que el cine combina elementos del sentido común para dotar de verosimilitud a sus relatos, legitimando o desacreditando diferentes ver- 
siones del discurso histórico, a partir de intereses ideológicos determinados. Nuestra hipótesis es que en el cine no se encuentra una suerte de reconstrucción verdadera de los hechos históricos, más bien existe una interpretación verosímil acerca de su significado social y político.

De allí que este texto se inscriba en una línea de estudio que afirma que, sin abandonar la función de entretención masiva, el cine es capaz de aspirar a reconstruir una era, un episodio y, también, visibilizar un proceso histórico, preguntándose qué hace el cine con el material y el discurso histórico; cómo utiliza la historia para producir imágenes verosímiles de la realidad; qué función asigna a los contextos históricos en la construcción de sus narrativas; en definitiva, cómo utiliza el discurso histórico para interpretar e imaginar las sociedades modernas.

TABLA 1

\section{Referencias Fílmicas}

1917 La agonía de Arauco, Gabriela Bussenius

1918 Todo por la patria (o El girón de la bandera), Arturo Mario, María Padín

1920 Manuel Rodríguez, Arturo Mario

1923 El odio nada engendra, Alberto Santana

1925 El húsar de la Muerte, Pedro Sienna

1926 Bajo dos banderas, Alberto Santana

1927/1934 A las armas, Nicanor de la Sotta

1944 Romance de medio siglo, Luis Moglia Barth

1947 Si mis campos hablaran, José Bohr

1968 Tierra quemada, Alejo Álvarez

1969 Caliche sangriento, Helvio Soto

1970 La Araucana, Julio Coli

1970 La casa en que vivimos, Patricio Kaulen

1971 El afuerino, Alejo Álvarez

1971 Frontera sin ley, Luis Margas

1971 Voto + fusil, Helvio Soto

1973 La tierra prometida, Miguel Littin

1974 A la sombra del sol, Silvio Caiozzi, Pablo Perelman

1979 Julio comienza en Julio, Silvio Caiozzi

1983 Ardiente paciencia, Antonio Skarmeta

1990 La niña en la palomera, Alfredo Rates

1991 La frontera, Ricardo Larraín

1992 Archipiélago, Pablo Perelman
1994 Amnesia, Gonzalo Justiniano

1996 Cicatriz, Sebastián Alarcón

1998 Cautiverio feliz, Cristián Sánchez

1999 El desquite, Andrés Wood

2000 Tierra del fuego, Miguel Littin

2002 El fotógrafo, Sebastián Alarcón

2003 Subterra, Marcelo Ferrari

2004 Machuca, Andrés Wood

2005 La última luna, Miguel Littin

2005 El baño, Gregory Cohen

2005 Mi mejor enemigo, Alex Bowen

2006/2011 Gente mala del norte, Patricio Riquelme

2007 Casa de remolienda, Joaquín Eyzaguirre

2007 Un salto al vacío, Pablo Lavín

2008 Tony Manero, Pablo Larraín

2009 Teresa, Tatiana Gaviola

2009 Dawson, Isla 10, Miguel Littin

2009 Grita, Paulo Avilés, Marcelo Leonart

2009 Monvoisin, Mario Velasco C.

2010 Post Mortem, Pablo Larraín

2010 La Esmeralda 1879, Elías Llanos Canales

2010 Cuatro hombres de ley, Sergio González Clavería

2010 Pinochet boys, Claudio del Valle

2010 El Inquisidor, Joaquín Eyzaguirre 
2011 La lección de pintura, Pablo Perelman

2011 Bonsai, Cristián Jiménez

2011 Violeta se fue a los cielos, Andrés Wood

2011 El tesoro del cráneo, Raúl Peralta Moris

2011 Bombal, Marcelo Ferrari

2011 Tiempos menos modernos, Simón Franco

2012 La pasión de Michelangelo, Esteban Larraín

2012 Miguel San Miguel, Matías Cruz

2012 No, Pablo Larraín

2013 La danza de la realidad, Alejandro Jorodowsky

2013 Patagonia sin sueños, Jorge López Sotomayor

2013 Las niñas Quispe, Sebastián Sepúlveda
2013 Videoclub, Pablo Illanes

2013 Cirqo, Orlando Lübbert

2013 El tío, Mateo Iribarren

2014 Allende en su laberinto, Miguel Littin

2014 Neruda, Manuel Basoalto

2014 El niño rojo, la película, Ricardo Larraín

2014 María Graham, Valeria Sarmiento

2015 El bosque de Karadima, Matías Lira

2016 Pinochet boys, Claudio del Valle

2016 Neruda, Pablo Larraín

2016 Poesía sin fin, Alejandro Jodorowsky

2016 Fuego en la Federación Obrera de Magallanes, Jorge Grez

\section{Referencias Bibliográficas}

Alsina, Miquel Rodrigo. La construcción social de la noticia. Barcelona, Paidós, 1998. Aumont, Jaques, Alain Bergala, Michel Marie y Marc Vernet. Estética del cine. Espacio fílmico, montaje, narración, lenguaje. Barcelona, Paidós, 1996.

Bettetini, Gianfranco y Armando Fumagalli. Lo que queda de los medios. Ideas para una ética de la comunicación. Pamplona, EUNSA, 2001.

Buonano, Milly. El drama televisivo. Identidad y contenidos sociales. Barcelona, Gedisa, 1999.

Caparrós, José María. “Enseñar la historia contemporánea a través del cine de ficción”. Quaderns de cine, n¹, 2007, pp. 25-35.

Cortés, Bárbara, y Álvaro Berríos. "La despolitización en la representación histórica de la Unidad Popular: Machuca (2004) de Andrés Wood”. La historia en el cine chileno de ficción (título provisorio). Ed. Hans Stange y Claudio Salinas. Santiago, Universitaria, [en prensa].

Ferro, Marc. El cine. Una visión de la historia. Madrid, Akal, 2008.

Foucault, Michel. El orden del discurso. Buenos Aires, Tusquets, 1992.

Goldmann, Lucien. "La importancia del concepto de conciencia posible para la comunicación”. La creación cultural en la sociedad moderna. Barcelona, Fontamara, 1980, pp. 9-24.

Gramsci, Antonio. El materialismo histórico y la filosofía de Benedetto Croce. Buenos Aires, Nueva visión, 1975.

Guzmán, Rayda. "Travesuras y extravagancias en torno al melodrama: la ficción produce efectos de verdad". Academia.edu, pp. 1-20, https://www.academia. edu/6112907/Travesuras_y_Extravagancias_en_torno_al_Melodrama_la_ ficci\%C3\%B3n_produce_efectos_de_verdad 
Hall, Stuart. "Representación, ideología: Althusser y los debates postestructuralistas". Estudios culturales y comunicación. Análisis, producción y consumo cultural de las políticas de identidad y el posmodernismo. Coord. James Curran, David Morley y Valerie Walkerdine. Barcelona, Paidós, 1998, pp. 23-61.

---. "El trabajo de la representación". Sin garantías. Trayectorias y problemas en estudios culturales. Lima, Envión-IEsc-Universidad Andina Simón Bolívar, 2010, pp. $445-480$.

Kriger, Clara, y Elina Tranchine. Problemas y debates fundamentales en los estudios sobre cine e historia. La Plata, Seminario de Doctorado, Universidad Nacional de La Plata, Facultad de Humanidades y Ciencias de la Educación, 2009.

Metz, Christian y Tzvetan Todorov, "El decir y lo dicho en el cine: ¿̇hacia la decadencia de un cierto verosímil?”. Lo verosímil. Comp. Verón Eliseo. Buenos Aires: Tiempo Contemporáneo, 1970, pp. 17-30.

Monterde, Enrique, Marta Selva y Anna Solá. La representación cinematográfica de la historia. Madrid, Akal, 2002.

Paoli, Antonio. "Hegemonía, sentido común y lenguaje". Comunicación y cultura, $\mathrm{n}^{\circ} 10,1983$, pp. $75-83$.

Richard, Nelly. "Memoria contemplativa y memoria crítico-transformadora. Sobre la película No de Pablo Larraín". La fuga, nº 16, 2014, http://www.lafuga.cl/ memoria-contemplativa-y-memoria-critico-transformadora/675

Rosenstone, Robert. El pasado en imágenes. El desafía del cine a nuestra idea de la historia. Barcelona, Ariel, 1997.

Rueda, José Carlos y María del Mar Chicharro. "La representación cinematográfica: una aproximación al análisis sociohistórico". Ámbitos, n¹1-12, 2004, pp. 427-450.

Sankey, Howard. "Ciencia, sentido común y realidad". Discusiones filosóficas, n¹6, 2010, pp. 41-58.

Santa Cruz Grau, José M. "Las formas representacionales de la historia en la trilogía de Pablo Larraín. Tony Manero, Post-Mortem y No". La historia en el cine chileno de ficción (título provisorio). Ed. Hans Stange y Claudio Salinas. Santiago, Universitaria, [en prensa].

Sorlin, Pierre. Sociología del cine. La apertura para historia del mañana. México DF, FCE, 1985.

White, Hayden. Ficción histórica, historia ficcional y realidad histórica. Buenos Aires, Prometeo, 2010.

Recibido: 24 enero 2017 Aceptado: 29 noviembre 2017 